\title{
Virtual Water Trade as a Strategy to Water Resource Management in Iran
}

\author{
F. Mohammadi-Kanigolzar*, J. Daneshvar Ameri, N. Motee \\ Department of Agriculture Development and Management, Faculty of Agriculture Economic and Development, \\ University of Tehran, Tehran, Iran \\ Email: *farhadmohammadi@alumni.ut.ac.ir
}

Received December 18, 2013; revised January 21, 2014; accepted February 11, 2014

Copyright (C) 2014 F. Mohammadi-Kanigolzar et al. This is an open access article distributed under the Creative Commons Attribution License, which permits unrestricted use, distribution, and reproduction in any medium, provided the original work is properly cited. In accordance of the Creative Commons Attribution License all Copyrights (C) 2014 are reserved for SCIRP and the owner of the intellectual property F. Mohammadi-Kanigolzar et al. All Copyright (C) 2014 are guarded by law and by SCIRP as a guardian.

\begin{abstract}
Agriculture has historically played a central role in the economy, life and culture of the Iranian population. Nowadays, this sector is facing the reality that its natural fresh water resources become fully utilized. Considering the climate conditions and limitation of using new water resources and the necessity of increasing agricultural product as a result of population growth, there is a general doubt about Iran's ability to maintain this level of production amid the mounting water challenges, among other obstacles. Therefore, the evaluation of virtual water and water footprint can provide new indicators for informing water policy decisions. So, in order to study the situation at the national level, we estimated virtual water consumption in term of virtual water theory as well water footprint in agriculture sector of Iran. Data from 2001-2008 were used to account for yearly. The results of this study show that Iran has water import dependency and also net water import is 12.7 billion $\mathbf{~ m}^{3}$ averages. So Iran country saved 12.7 billion $\mathbf{~ m}^{3}$ from their domestic water resource for utilization in other sectors. Finally, it should be concluded that virtual water trade as a policy measure to water resources management will be provided to a great extent in order to reach both significant water saving and environmental sustainability.
\end{abstract}

\section{KEYWORDS}

Virtual Water; Footprint; Water Resource Management; Environmental; Iran

\section{Introduction}

There are many studies concerning the increasing threat of water scarcity and vulnerability of water resources at regional and global scales [1-3]. With no significant room to expand cultivation areas in water scarce regions, increased demand for food will have to be met through sustainable agricultural production, which entails improved management of the available resources and development of crop production strategies [4], as well as import from outside $[5,6]$. Since in water scarce countries, agriculture sector has the highest rate of consumption water among the various sectors, the main focus of most water scarcity studies is on the impact on agricultural and food security.

Iran is located in dry area, large parts of which are characterized as arid and semi-arid environment. Accord-

"Corresponding author. ing to predictions, Iran's population will reach 100 million by 2021 and this will result in a drastic drop in the water per capita. Self-sufficiency in wheat production, self-reliance in the production of some strategic goods, and great investment in the implementation of infrastructural water projects are needed to meet this population's water and food demands. On the other hand, the need for industrial development, eradication of poverty, the creation of job opportunities and the construction of economic infrastructure in order to achieve the minimum economic and social indices, and a move in coordination with the world economy, have created problems as far as meeting financial demands is concerned. Issues such as high water consumption in the agricultural sector (more than $90 \%$ of clean water) and the low output of irrigation clearly show that these two sectors have to be strengthened in the country. However, there is a general doubt 
about Iran's ability to maintain this level of production amid the mounting water challenges, among other obstacles.

Virtual water, however, can be used in water-scarce countries such as Iran, so that they can use it as a way to relieve the pressure on water resources, and accordingly, as an alternative in the demand management [7]. Allan elaborated on the idea of using virtual water import (coming along with food imports) as a tool to release the pressure on the scarcely available domestic water resources. Virtual water import thus becomes an alternative water source, next to endogenous water sources. Imported virtual water has also been called "exogenous water" [8]. Measuring virtual water is a useful concept in assessing water resource management as it permits the comparison of crops and livestock from the perspective of embedded water [9]. A number of studies have recognized the usefulness of the concept of virtual water for analyzing production patterns and associated water flows [10]. For example, the average global volume of virtual water flows related to the international trade in agricultural products was $1263 \mathrm{Gm}^{3} / \mathrm{yr}$ in the period 1997-2001 by Chapagain and Hoekstra [11]. This estimate is based on the virtual water content of the products in the exporting countries. It would be interesting to see the volume of virtual water trade internationally based on the virtual water content of the products in the importing countries. In addition, in many countries, international trade in agriculture products effectively reduces domestic water demand. These countries import commodities that are relatively water intensive while they export commodities that are less water intensive. In the period 19972001, Japan, the largest (net) importer of water-intensive goods in the world, annually saved 94 billion $\mathrm{m}^{3}$ from its domestic water resources. This volume of water would have been required, in addition to its current water use, if Japan had produced all imported products domestically. In a similar way, Mexico annually saved 65 billion $\mathrm{m}^{3}$, Italy 59 billion $\mathrm{m}^{3}$, China 56 billion $\mathrm{m}^{3}$ and Algeria 45 billion $\mathrm{m}^{3}$ [12].

Besides, there are plenty studies about virtual water trade. Some researchers have been working on a specific crop farming [12]. Some have looked at the trade aspects from the national or local perspectives, for example, Earle et al. [13] \& Guan and Hubacer [14]. Others have tried to make the analysis of international trade and virtual water put together, for example, Hoekstra and Yang [15] \& Chapagain and Hoekstra [11].

So the evaluation of virtual water and water footprint can provide new indicators for informing water policy decisions. Water footprint of a country or region is the total volume of water resources required of the production of the goods and services consumed by a defined population during a given period time [16]. With similar ecological footprint, the virtual water trade (VWT) that introduced by Allan [6] has been seen as one of the ways to improve water use efficiency and to mitigate water scarcity at the regional level and interregional food trade $[16,17]$. At the national level, food self-sufficiency has been a desired objective of the Iranian government; nevertheless, large amounts of food are imported into the country in drought years. This is partly due to the lack of water for expanding agricultural production. Wheat import during the drought years of 1999 to 2001 accounted for $80 \%$ of the country's total domestic wheat supply, making Iran one of the largest wheat importers of the world at the time [18]. Given the close relationship between water and food, a systematic assessment of water resources availability with high spatial and temporal resolution is essential in Iran for strategic decision making on food security.

The present study evaluates the agricultural water footprint and virtual water "flows" through primary crops in Iran differentiating the green and blue water components. This paper is motivated, in part, by a few but crucial methodological issues that question current virtual water and water footprint evaluations for Iran [11]. Therefore, the main objectives of the present work are 1) to obtain new evaluations of both water footprint and virtual water "flow" at a lower spatial scale and for different years; 2) to evaluate water scarcity in light of the evaluations of water footprint and virtual water "flows"; and 3) to distill water policy lesson from these results. Data from 2001-2008 were used to account for yearly.

\section{Study Area}

Geographically, Iran is located between 25 - 40 degrees north latitude and 44 - 63 degrees east longitude with total area of about 1.648 million $\mathrm{km}^{2}$. Climatic conditions of Iran are mostly typical of arid and semi-arid regions of the Middle East. Nevertheless, the country has a wide spectrum of climatic, physiographic, edaphic, and hydrological conditions. The country-wide average precipitation is about $252 \mathrm{~mm} \cdot$ year $^{-1}$. The per capita freshwater availability for the country was estimated at around $2000 \mathrm{~m}^{3} \cdot$ capita $^{-1} \cdot$ year $^{-1}$ in the year 2000 and expected to go below $1500 \mathrm{~m}^{3} \cdot$ capita $^{-1} \cdot$ year $^{-1}$ by 2030 due to population growth [17]. Winter temperatures of less than $-20^{\circ} \mathrm{C}$ in high altitude of the country and summer temperatures of more than $50^{\circ} \mathrm{C}$ in some areas are recorded [19]. Of total land area of the country $12 \%$ is under cultivation (arable land, orchards and vineyards). About 9 million hectares of this land are irrigated using traditional and modern techniques, around 6.5 million hectares are rain fed, and the rest is fallow every year.

\section{Methodology}

In this study, virtual water of 34 important agricultural 
products $\left(\mathrm{m}^{3} / \mathrm{ton}\right)$ was estimated based on crop water requirements and yields. These products categorized in different groups such as legumes, fruits, industrial crops, oil seeds, dried fruit, summer crops, selected fodder crops, Tea and Saffron. However, to calculation of virtual water and virtual water trade flow process was used of the methods provided by Chapagain et al. [16], Chapagain and Hoekstra [11]. Furthermore, the processing water requirement is calculated as follows Chapagain and Hoekstra [11]. For water footprint calculation we used the methodology described by Hoekstra and Hung [15] and Van Oel et al. [20]. Water footprint of a country or region is the total volume of water resources required of the production of the goods and services consumed by a defined population during a given period time [2006]. To calculate the water footprint offered two method of Top-down and Bottom-up, but in this approach, to asses water footprint (Top-down method), we subtracted virtual water export and added virtual water import to total national water withdrawal. National water scarcity, water dependency on foreign water resources and sustainability of national consumption (water self-sufficiency) indexes had calculated to explain relation between water scarcity and virtual water import of country according to Hoekstra and Hung [21] and Arabi et al. [22].

The information about yield of crops, water requirement for each crop, crop productivity and water resource is derived from Power and Agriculture ministry and also FAOSTAT. Required data about Iranian trade have been taken from Agriculture ministry, FAO and Statistics of exports and imports of agricultural commodities and food industries, published by the Iran Chamber of Commerce, Industries, Mines and agriculture for during 2000-2009. Information for adaptive capability collected from Agriculture ministry, FAO, Statistical Center of Iran and the World Bank.

\section{Analysis of the Results}

Table 1, illustrates the mean water requirement, yield, amount of virtual water and water productivity of the products that has been evaluated for during the 20012008 in Iran. As can be seen, among the crops, the average cane and date palm have the greatest water requirements and also the tobacco and kiwi have the least. Plant water demand represents the minimum amount of water required for the activity of physiology and evapotranspiration.

Virtual water content of each crop is different due to climate change and yield in the period of survey. So the average virtual water for products was calculated in 2001-2008. Based on the results, among the imported products respectively, sunflower, lentils, cotton and soybean and also in the exports crops saffron, pistachios, almonds, walnuts and chickpeas have the maximum amount of virtual water. In addition, average annual virtual water for exports and imports crops represented that the virtual water content (especially water demand) of products have been exported more than import products. In fact, in the current circumstances the amount of imports (in terms of volume) is much more than the amount of export (in terms of volume).

The averages of virtual water content $\left(\mathrm{m}^{3} \cdot \mathrm{ton}^{-1}\right)$ in separated categories of agricultural products in 2001-2008 are shown in Figure 1. Grains, summer crops, fruits, fodder crops and tea have virtual water content more than the virtual water standard limit as $1000\left(\mathrm{~m}^{3} \cdot \mathrm{ton}^{-1}\right)$. So, they are included water-intensive products. Virtual water content of each type of crop depends on crop water requirements, climate conditions, and crop productivity and irrigation efficiency. Of course, the Saffron (export crop) is in those products which have very high virtual water this is because the low yield per hectare.

\subsection{Virtual Water Trade Flow in Agricultural Products}

Tables $2 \& 3$ show the virtual water trade related to agricultural crop trade in import and export groups respectively. The production trade causes virtual water flow which import/export water in virtual form to/from nation. It is found that the largest volume of products which are shared in import and export in 2001-2008.

From the Table 2, it can be seen that in during the period studied the productions such as corn, wheat and sugarcane, respectively, with the 2.894, 2.581 and 2.003 (billion cubic meters per year) has the highest amount of virtual water import. These results due to high level of imports of its crops were expected. In addition, Crude oil, soya and sunflower in the ranking for the next. The results were expected since the high amount of virtual water in raw product and import value. Based on this data, the total virtual water import into the country in 2008 (Greatest imports in this year due to low rainfall in the country) with a $22.813 \times 10^{9}\left(\mathrm{~m}^{3} \cdot \mathrm{yr}^{-1}\right)$ had the largest

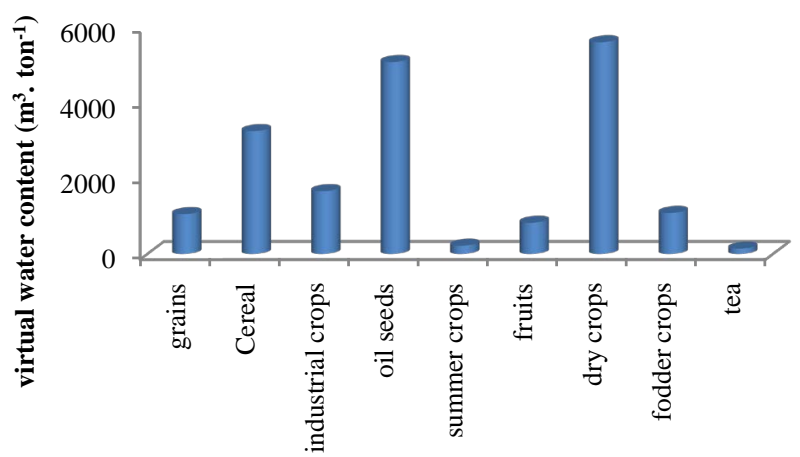

Figure 1. The average of virtual water content $\left(\mathrm{m}^{3} \cdot \operatorname{ton}^{-1}\right)$ in different groups of Agricultural products in 2001-2008. 
Table 1. Yield, water requirement (CWR), virtual water crop (VWC), water productivity (CWP), 2001-2008.

\begin{tabular}{|c|c|c|c|c|}
\hline Crops & Yield (kg/ha) & $\mathbf{C W R}\left(\mathrm{m}^{3} \cdot \mathrm{ha}^{-1}\right)$ & VWC $\left(\mathrm{m}^{3} \cdot \operatorname{ton}^{-1}\right)$ & $\mathbf{C W P}\left(\right.$ ton $\left.\cdot \mathrm{m}^{-3}\right)$ \\
\hline Wheat & 3536 & 3615 & 1022.37 & 0.98 \\
\hline Barley & 2987 & 2964 & 992.31 & 1.01 \\
\hline Rice & 4310 & 4275 & 991.81 & 1.01 \\
\hline Maize & 6790 & 8208 & 1208.86 & 0.83 \\
\hline Lentil & 1107 & 3870 & 3496.90 & 0.29 \\
\hline Cotton & 2427 & 7644 & 3149.74 & 0.32 \\
\hline Tobacco & 1464 & 2353 & 1607.45 & 0.62 \\
\hline Cane & 83062 & 18924 & 227.82 & 4.39 \\
\hline Soybean & 2327 & 3145 & 1351.47 & 0.74 \\
\hline Banana & 26278 & 9404 & 357.86 & 2.79 \\
\hline Sunflower & 574th & 5061 & 8820.72 & 0.11 \\
\hline Pea & 1027 & 3872 & 3769.82 & 0.27 \\
\hline Beans & 1957 & 4880 & 2493.09 & 0.40 \\
\hline Potato & 24720 & 6145 & 248.58 & 4.02 \\
\hline Onions & 34501 & 7579 & 219.67 & 4.55 \\
\hline Tomatoes & 33434 & 4863 & 145.45 & 6.88 \\
\hline Watermelon & 26653 & 5917 & 222.00 & 4.50 \\
\hline Cucumber & 20776 & 5248 & 252.59 & 3.96 \\
\hline Alfalfa & 8196 & 8897 & 1085.49 & 0.92 \\
\hline Orange & 17071 & 6532 & 382.62 & 2.61 \\
\hline Date palm & 5251 & 13794 & 2626.80 & 0.38 \\
\hline Kiwi & 24177 & 2779 & 114.94 & 8.70 \\
\hline Tea & 19869 & 2776 & 139.71 & 7.16 \\
\hline Saffron & 3 & 3000 & 867804 & 0.00 \\
\hline Apple & 16387 & 6732 & 410.80 & 2.43 \\
\hline Fresh grapes & 11448 & 6256 & 546.47 & 1.83 \\
\hline Pistachio & 671 & 5174 & 7710.34 & 0.13 \\
\hline Fig & 7289 & 9730 & 1334.91 & 0.67 \\
\hline Almonds & 1317 & 7333 & 5565.96 & 0.18 \\
\hline Walnut & 2522 & 8971 & 3556.54 & 0.28 \\
\hline
\end{tabular}

Table 2. The amount of virtual water imported in 2001-2008. Unit: billion cubic meters per year.

\begin{tabular}{|c|c|c|c|c|c|c|c|c|c|}
\hline product & 2001 & 2002 & 2003 & 2004 & 2005 & 2006 & 2007 & 2008 & average \\
\hline wheat & 8.015 & 2.86 & 0.73 & 0.161 & 0.1 & 1.112 & 0.18 & 7.493 & 2.581 \\
\hline barely & 1.056 & 0.024 & 0.175 & 0.773 & 1.175 & 0.352 & 0.187 & 1.687 & 0.678 \\
\hline maize & 2.28 & 2.078 & 4.568 & 2.337 & 2.401 & 3.216 & 2.825 & 3.452 & 2.894 \\
\hline lentil & 0.026 & 0.002 & - & - & 0.007 & 0.052 & 0.032 & 0.168 & 0.047 \\
\hline tobacco & 0.008 & 0.032 & 0.049 & 0.063 & 0.064 & 0.073 & 0.079 & 0.072 & 0.055 \\
\hline cane & 2.045 & 1.419 & 0.412 & 0.289 & 1.361 & 4.798 & 1.994 & 3.708 & 2.003 \\
\hline soybean & 1.112 & 0.436 & 1.096 & 1.066 & 0.938 & 1.384 & 1.058 & 0.991 & 1.010 \\
\hline banana & 0.04 & 0.058 & 0.086 & 0.088 & 0.154 & 0.592 & 0.205 & 0.2 & 0.177 \\
\hline sunflower & - & - & 0.001 & 0.001 & 0.009 & 0.001 & 0.005 & 0.009 & 0.004 \\
\hline Soybean meal & 2.004 & 1.479 & 1.161 & 1.376 & 0.255 & 1.295 & 1.563 & 1.54 & 1.334 \\
\hline crude soybean oil & 3.233 & 1.935 & 1.935 & 1.454 & 1.78 & 1.749 & 1.568 & 0.821 & 1.809 \\
\hline crude sunflower oil & 1.132 & 1.829 & 3.442 & 0.285 & 0.569 & 1.887 & 2.694 & 1.028 & 1.608 \\
\hline total & 21.724 & 13.102 & 14.454 & 9.144 & 9.913 & 17.893 & 13.655 & 22.813 & \\
\hline
\end{tabular}


Table 3. The amount of virtual water exported in 2001-2008. Unit: billion cubic meters per year.

\begin{tabular}{|c|c|c|c|c|c|c|c|c|c|}
\hline product & 2001 & 2002 & 2003 & 2004 & 2005 & 2006 & 2007 & 2008 & average \\
\hline Pea & 0.673 & 0.566 & 0.3 & 0.267 & 0.249 & 0.23 & 0.001 & 0.038 & 0.291 \\
\hline Beans & 0.011 & 0.015 & 0.003 & 0.003 & 0.011 & 0.013 & 0 & 0.001 & 0.007 \\
\hline Potato & 0.035 & 0.018 & 0.01 & 0.01 & 0.053 & 0.044 & 0.012 & 0.094 & 0.035 \\
\hline Onion & 0.02 & 0 & 0.017 & 0.009 & 0.005 & 0.033 & 0.048 & 0.021 & 0.019 \\
\hline Tomatoes & 0.003 & 0.963 & 0.008 & 0.003 & 0.004 & 0.013 & 0.015 & 0.012 & 0.128 \\
\hline Watermelon & 0.023 & 0.021 & 0.019 & 0.02 & 0.035 & 0.042 & 0.063 & 0.05 & 0.034 \\
\hline Cucumber & 0.001 & 0.002 & 0.003 & 0.009 & 0.011 & 0.022 & 0.038 & 0.064 & 0.019 \\
\hline Alfalfa & - & - & 0.002 & 0 & 0.006 & 0.014 & 0.002 & 0.017 & 0.007 \\
\hline Orange & 0.004 & 0.002 & 0.002 & 0.011 & 0.005 & 0.008 & 0.003 & 0.001 & 0.005 \\
\hline Date palm & 0.324 & 0.323 & 0.291 & 0.234 & 0.298 & 0.415 & 0.318 & 0.282 & 0.311 \\
\hline Kiwi & 0.001 & 0.001 & 0.002 & 0.003 & 0.003 & 0.003 & 0.003 & 0.005 & 0.003 \\
\hline Tea & 0.003 & 0.002 & 0.001 & 0.01 & 0.004 & 0.011 & 0.015 & 0.001 & 0.006 \\
\hline Saffron & 0.1 & 0.084 & 0.143 & 0.154 & 0.144 & 0.092 & 0.066 & 0.313 & 0.137 \\
\hline Apple & 0.041 & 0.037 & 0.068 & 0.029 & 0.079 & 0.075 & 0.097 & 0.147 & 0.072 \\
\hline Fresh grape & 0.001 & 0.002 & 0.004 & 0.003 & 0.004 & 0.008 & 0.007 & 0.004 & 0.004 \\
\hline Pistachio & 1.546 & 0.934 & 1.189 & 1.252 & 1.073 & 1.071 & 1.3 & 1.078 & 1.180 \\
\hline Fig & 0.013 & 0.01 & 0 & 0.012 & 0.01 & 0.009 & 0.012 & 0.007 & 0.009 \\
\hline Almond without skin & 0.199 & 0.077 & 0.017 & 0.021 & 0.012 & 0.015 & 0.013 & 0.015 & 0.046 \\
\hline Walnut & 0.003 & 0.003 & 0.004 & 0.001 & 0.002 & 0.003 & 0.002 & 0.002 & 0.003 \\
\hline Currant & 0.259 & 0.27 & 0.303 & 0.287 & 0.293 & 0.339 & 0.309 & 0.247 & 0.288 \\
\hline Total & 3.261 & 3.328 & 2.386 & 2.337 & 2.302 & 2.461 & 2.321 & 2.397 & \\
\hline
\end{tabular}

share of the total imports of virtual water but in other hands, in 2004 the amount of $9.144 \times 10^{9}\left(\mathrm{~m}^{3} \cdot \mathrm{yr}^{-1}\right)$ the lowest proportion of the total virtual water import into the country has had.

Virtual water import of various groups of products is shown in Figure 2. As can be seen in grains groups "wheat, barley, rice and corn" are as the most important group of virtual water import in during the studied period. This can be due to high imports of grains (especially wheat) was discussed during the survey. Overall share of different groups of virtual water import value during the period are as follows: grains 46.8 percent, oil seeds 37.3 , Industrial Products 14.3, fruit 1.14 percent and legumes 0.34 percent.

\subsection{Virtual Water Export of Agricultural Products}

Table 3 is shown the virtual water export of various products. As it can be seen that the average of during the period, respectively, pistachio, date palm, currant and

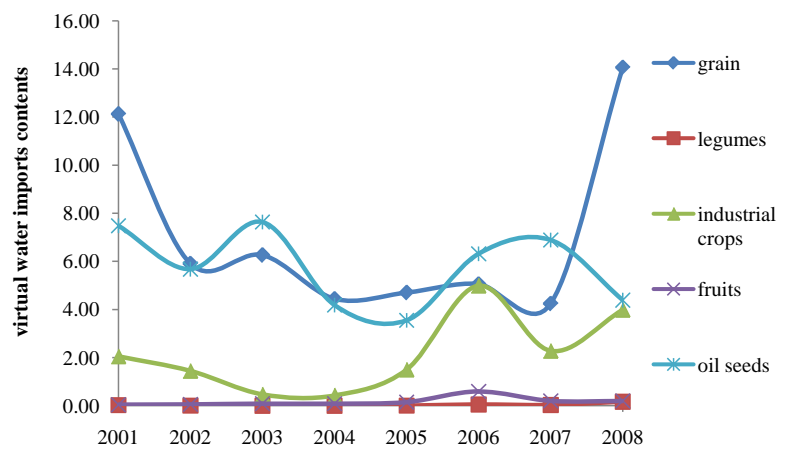

Figure 2. The virtual water imports (billion cubic meters per year) of various products Group during the 2001-2008 in Iran.

peas, respectively, with $1.180,0.311,0.291$ and 0.288 (billion cubic meters per year) has the maximum amount of virtual water exports. However, while virtual water content (especially demand water) of products likes nuts and dates was high. In other hands, although the grapes crop as the product of basic for the preparation of currant 
haven't high virtual water, however, the cause of currant has a significant export, hence virtual water exports content was high.

In addition, the total virtual water exports from the country in 2001 with a value of $3.328 \times 10^{9}\left(\mathrm{~m}^{3} \cdot \mathrm{yr}^{-1}\right)$ accounted the highest share of total exports of virtual water in during the studied period. Also in 2008 with a value of $2.302 \times 10^{9}\left(\mathrm{~m}^{3} \cdot \mathrm{yr}^{-1}\right)$ has the lowest share of virtual water exports.

Figure 3 illustrates the virtual water exports (billion cubic meters per year) of various products Group during the 2001-2008 in Iran. However, dried fruit Group (pistachios, walnuts, almonds and currant) with 57.8 percent was at the largest export amount of virtual water, so from the virtual water exports was as the most important groups in during the studied period. Furthermore, share of different groups of virtual water exports value during the period are as follows: fruits (oranges, date palm, kiwi, apples and grapes) 16.2 percent, legumes (peas and beans) 10.9 percent, vegetable and melon crops (potatoes, onions, tomatoes, tomatoes, watermelons, and cucumbers) $9.3 \%$, saffron $5.2 \%$, fodder crops $0.25 \%$ and tea $0.21 \%$ have been in the next category of virtual water export crops. In general it can be said that the export of virtual water in legumes had a decreasing trend, of course a reason for this can to be low commercial performance in this product.

\subsection{Net virtual Water Import}

Net virtual water content in relation to import and export products illustrates in Figure 4. The positive amounts mean that these groups are more import than export virtual water and the negative amounts mean that these groups are more export than import virtual water. This graph shows Iran imported net virtual water about 18.56 (bcm) in 2001 to 20.72 (bcm) in 2008, due to importing agricultural products and exported $1.6 \mathrm{bcm}$ water in virtual form. The net virtual water of Iran in 2006 was about 11.64 (bcm). Average of this index for the period study

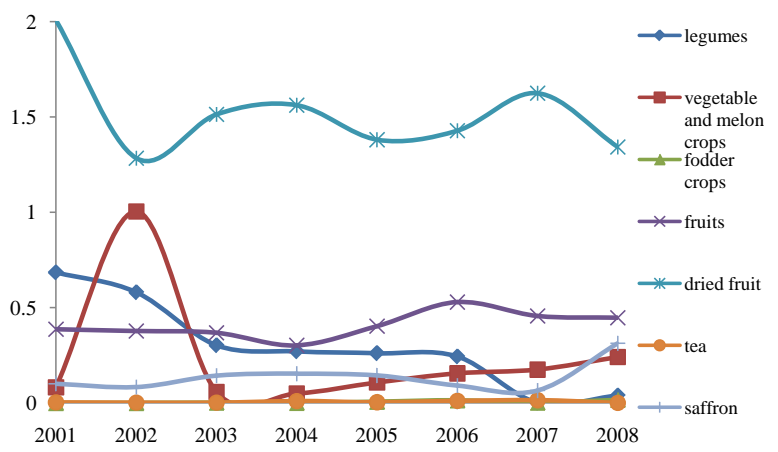

Figure 3. The virtual water exports (billion cubic meters per year) of various products Group during the 2001-2008 in Iran.

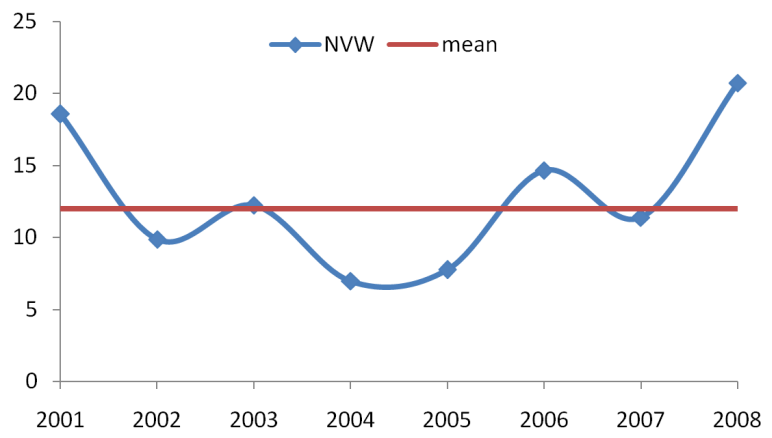

Figure 4. The net virtual water import of different agricultural products in 2001-2008.

was 13.7 (bcm). The maximum amount of net virtual water import appeared in 2008, and the lowest in 2004. Hence, it can be said that net virtual water import most effect of virtual water import.

Generally, the net virtual water imports during the studied period were more affected of grains, especially wheat. Such that in the years the levels of import grain was high, net imports high and vice versa (These studies, like Hoekstra and Hung [21], Chapagain and Hoekstra [11], Ramirez and Rogers [2004] and Arabi et al. [22], have earned a positive net virtual water import).

Table 4 illustrates the founding about water footprint, Water Scarcity, virtual water dependence and water Selfsufficiency indicators. Survey the condition of water Footprint Index indicated that this index has been uneven over the years studied. Since this index is components of two parts; total domestic water use and net virtual water import. Thus, increasing net virtual water import will be increase water footprint. It has been expected that this increase will reduce pressure on domestic water resources. However, it is clear that the amount of water footprint in the years that the country is as importer is high, for both 2008 and 2001 (the lowest rainfall in these years, diagram 1).

Water Scarcity which increase with the rising net virtual water imports, in other words, there is a Positive correlation between of net virtual water import and water scarcity. The study of virtual water import dependency of the study shows that the level of index has increased. The average amount of it in during the years of period was 12.7 billion cubic meters per year. This means that if a country production domestically crops than imports agricultural products, should be added $12.7 \mathrm{bcm}$ of internal water resource for production that crops.

The water self-sufficiency index (is as opposed index, the virtual water import dependency, that increase in this index will be decreased dependency) is defined as a proportion of domestic water footprint to the total water footprint of a country or region. Self-sufficiency is $100 \%$ if all the water needed is available and indeed taken from within the own territory. Water self-sufficiency ap- 
Table 4. The index amounts of water Self-sufficiency (WSS), water Dependence (WD), Water Scarcity (WS), Water Footprint (WF).

\begin{tabular}{|c|c|c|c|c|}
\hline \multirow{2}{*}{ Year } & \multirow{2}{*}{ WF } & WS & WD & WSS \\
\hline & & $\%$ & $\%$ & $\%$ \\
\hline 2001 & 111.11 & 85 & 16.71 & 83.29 \\
\hline 2002 & 102.67 & 80 & 9.61 & 90.39 \\
\hline 2003 & 105.31 & 81 & 11.6 & 88.40 \\
\hline 2004 & 100.19 & 78 & 6.95 & 93.05 \\
\hline 2005 & 100.95 & 77 & 7.68 & 92.32 \\
\hline 2006 & 107.74 & 82 & 13.59 & 86.41 \\
\hline 2007 & 104.20 & 80 & 10.94 & 89.06 \\
\hline 2008 & 113.21 & 87 & 18.31 & 81.69 \\
\hline
\end{tabular}

proaches zero if the demands of goods and services in a country are heavily met with gross virtual water imports, i.e. it has relatively large external water footprint in comparison to its internal water footprint. The water self-sufficiency index shows a decreasing trend of this index in during the period 2001-2008. In other words, the demand for a product or service into country has been met plenty of by imports of virtual water.

However, due to population growth and other sectors competitiveness with the agriculture in water consumption, expected that indicators of water scarcity and dependence are moving into the third (High water scarcity and water dependency increases).

\section{Conclusions}

In this paper, we estimated virtual water consumption in term of virtual water theory in agriculture sector of Iran. Furthermore, national water scarcity, water dependency on foreign water resources, and sustainability of national consumption (water self-sufficiency) index, have been calculated to explain relation between water scarcity and virtual water import of Iran. In addition, water resources utilization of this sector by the method of water footprint was analyzed. The findings in this paper are the following:

Calculations of the virtual water content of selected products indicate that exported products had been more specific water demand than imported products. In other words, the pattern of agricultural export during the period has been towards the export of water. Also, the results show that in the equal volume of trade, export of virtual water will be several times more than imports. These are notable cases in determining the pattern of virtual water trade.

The investigation showed that virtual water trade of the country has not been identified due to water condi- tions. Meanwhile, some of the goods that require less water and have high economic efficiency advantage have been placed on imported products, while many exported goods have a high specific water demand, that is to say, irrational use of water resources development in Iran. It seems that it is necessary to review water resource management policies and incorporate the development of virtual water resources based on comparative advantage, with the cooperation of all national and international sectors. During recent years, Iran has been one of the major importers of virtual water. Undoubtedly, the consideration of virtual water in the country's international and national water policies is in need as follows:

1. However, it seems that some of the decision makers have no reluctance to accept the role of virtual water in agricultural trade, but, in order to achieve the sustainable use of water resources, maximum use of existing capacities in this section is required.

2. A model of cultivation with a focus on virtual water and water resources in each region should be developed, because the current approach of self-sufficiency in local levels up to international level would be the loss of potential and water resource due to the lack of such a calculation.

3. Label installation of virtual water on the agricultural production, such as energy labels installed on industrial products, can be effective to promote knowledge and also optimize the use of agricultural products.

4. Fluctuation in production due to the lack of uniformity of rainfall is one of the features of Iran, which is harmful to the stability and security of food supplies. Iran has the large share of imports, so fluctuation in production may lead to increasing volatility in imports which can also affect the stability of global food markets. Changing the economic system to virtual water would allow the country to guarantee food security, and the 
production of low-cost desalinated seawater is able to support the domestic and industrial needs.

\section{REFERENCES}

[1] S. L. Postel, G. C. Daily and P. R. Ehrlich, "Human appropriation of renewable freshwater," Science, Vol. 271, No. 5250, 1996, pp. 785-788.

http://dx.doi.org/10.1126/science.271.5250.785

[2] C. J. Vörösmarty, P. Green, J. Salisbury and R. B. Lammers, "Global Water Resources: Vulnerability from Climate Change and Population Growth,” Science, Vol. 289, No. 5477, 2000, pp. 284-288. http://dx.doi.org/10.1126/science.289.5477.284

[3] T. Oki and S. Kanae, "Global Hydrological Cycles and World Water Resources,” Science, Vol. 313, No. 2790, 2006, pp. 1068-1072. http://dx.doi.org/10.1126/science.1128845

[4] M. Qadir, B. R. Sharma, A. Bruggeman, R. Choukr and F. Allah Karajeh, "Nonconventional Water Resources and Opportunities for Water Augmentation to Achieve Food Security in Water Scarce Countries," Agricultural Water Management, Vol. 87, No. 1, 2007, pp. 2-22. http://dx.doi.org/10.1016/j.agwat.2006.03.018

[5] H. Yang, L. Wang, K. C. Abbaspour and A. J. B. Zehnder, "Virtual Water Trade: An Assessment of Water Use Efficiency in the International Food Trade," Hydrology and Earth System Sciences, Vol. 10, 2006, pp. 443-454. http://dx.doi.org/10.5194/hess-10-443-2006

[6] J. A. Allan, "Virtual Water: A Long Term Solution for Water Short Middle Eastern Economies," Occasional Paper 3, School of Oriental and African Studies (SOAS), University of London, 1997.

[7] V. Esther, "Water Trade in Andalusia. Virtual Water: An Alternative Way to Manage Water Use," Ecological Economics, Vol. 63, No. 1, 2006, pp. 201-208.

[8] M. J. Haddadin, "Exogenous Water: A Conduit to Globalization of Water Resources, Virtual Water Trade,” In: A. Y. Hoekstra, Ed., Proceedings of the International Expert Meeting on Virtual Water Trade, Value of Water Research Report Series No. 12, 2003.

[9] L. R. Brown, C. Scott, A. M. Craig, L. L. Joanna, M. Frank, P. Elizabeth, R. S. Arnold, L. N. Frederick, P. Hilda and S. José, "The Relationship of Built Environment to Perceived Social Support and Psychological Distress in Hispanic Elders: The Role of 'Eyes on the Street',' The Journals of Gerontology Series B: Psychological Sciences and Social Sciences, Vol. 64, No. 2, 2009, p. 234. http://dx.doi.org/10.1093/geronb/gbn011

[10] M. Zeitoun, J. A. Allan and Y. Tony, "Virtual Water 'Flows' of the Nile Basin, 1998 - 2004: A First Approxi- mation and Implications for Water Security,” Global Environmental Change, Vol. 20, No. 2, pp. 229-242. http://dx.doi.org/10.1016/j.gloenvcha.2009.11.003

[11] A. K. Chapagain and A. Y. Hoekstra, "Water Footprints of Nations," Value of Water Research Report Series, Vol. 1-2, UNESCO-IHE, Delft, 2004.

[12] A. Y. Hoekstra, "The Role of Virtual Water Transfer in Water Management,” International Workshop on European Water Scenarios: From the Mediterranean Sea to Central Asia, Brussels, 2003.

[13] A. Earle and A. Turton, "The Virtual Water Trade amongst Countries of the SADC, Virtual Water Trade," In: A. Y. Hoekstra, Ed., Proceedings of the International Expert Meeting on Virtual Water Trade, Value of Water Research Report Series No. 12, 2003.

[14] D. Guan and K. Hubacer, "Analysis: Assessment of Regional Trade and virtual Water Flows in China," Ecological Economics, Vol. 63, No. 1, 2007, pp. 159-170.

[15] A. Y. Hoekstra and P. Q. Hung, "Globalization of Water Resources: International Virtual Water Flows in Relation to Crop Trade,” Global Environmental Change, Vol. 15, No. 1, 2005, pp. 45-56. http://dx.doi.org/10.1016/j.gloenvcha.2004.06.004

[16] A. K. Chapagain, A. Y. Hoekstra and H. G. Savenije, "Water Saving through International Trade of Agricultural Products,” Hydrology and Earth System Sciences, 2006, Discuss 2. www.Copernicus.org/EGU/hess/hessd/2.

[17] H. Yang and A. Zehnder, "Virtual Water: An Unfolding Concept in Integrated Water Resources Management," Water Resources Research, Vol. 43, No. 12, 2007, Article ID: W12301. http://dx.doi.org/10.1029/2007WR006048

[18] Food and Agriculture Organization of United Nations, 2006. http://faostat.fao.org/site/342/default.aspx

[19] NCCO, "Initial National Communication to United Nations Framework Convention on Climate Change,” Iranian National Climate Change Office at Department of Environment, Tehran, Iran, 2003.

[20] P. R. Van Oel, M. M. Mekonnen and A. A. Hoekstra, "The External Water Footprint of the Netherlands: Quan-tification and Impact Assessment,” Value of Water Research Report Series No. 33, UNESCO-IHE, Delft, 2008.

[21] A. Y. Hoekstra and P. Q. Hung, "Virtual Water Trade: A Quantification of Virtual Water Flows between Nations in Relation to International Crop Trade,” Value of the Water Research Report Series No. 11, UNESCO-IHE, Delft, 2002.

[22] A. Arabi, A. Alizadeh Y. Vahab Rajee, K. Jam and N. Niknia, "Study on Ecological Water Footprint in Agricultural Section of Iran,” Journal of Water Resource and Protection, Vol. 4, 2012, pp. 318-324. 